\title{
INFLUENCE OF LANDSCAPE CHARACTERISTICS ON CAPYBARA ROAD-KILL ON HIGHWAY BR-040, SOUTHEASTERN BRAZIL
}

\author{
Cecilia Bueno ${ }^{1}$, Mariana T. Faustino ${ }^{2}$ \& Simone R. Freitas ${ }^{2}$
}

\footnotetext{
${ }^{1}$ Universidade Veiga de Almeida (UVA), Rua Ibituruna 108, Rio de Janeiro, RJ, Brazil. CEP: 20271-901.

${ }^{2}$ Universidade Federal do ABC (UFABC), Rua Santa Adélia 166, Bloco A, Torre 3, sala 631-3, Santo André, SP, Brazil. CEP: 09210-170.

E-mails: cecilia.bueno@pobox.com, mariana.tambellini@gmail.com, simonerfreitas.ufabc@gmail.com
}

\begin{abstract}
Motor vehicles colliding with large- and medium-sized mammals on highways may cause serious accidents, including loss of human lives or substantial material damages. Predicting the sites of highest incidence of the collisions is a relevant matter to propose mitigation measures, and this is done by using models that relate collision occurrences with landscape characteristics of the surroundings. Capybaras are one of the largest mammals in the tropics and the most common victims of vehicle collisions in Brazil. This work aimed to determine which landscape characteristics are related to capybara road-kill along $180.4 \mathrm{~km}$ of the BR-040 Highway between Rio de Janeiro and Juiz de Fora cities, Southeastern Brazil. Capybaras were monitored for 4 years, and 51 road-kills were registered. The landscape characteristics assessed within $1 \mathrm{~km}$ of the road-kill were quantified as: urban area, forest cover, herbaceous cover, crop fields and distance of the nearest river. Afterwards, logistic regression models were generated, and the best were selected by Akaike's Information Criterion. The occurrence of capybara road-kills was mainly associated with river proximity, but also high herbaceous cover and low forest cover was relevant. Landscape characteristics found to be relevant are indeed related to the habitat of these social and semi-aquatic mammals that prefer to be near open areas and water bodies. Some mitigation measures are proposed to reduce collisions with these animals, including installation of signs and fences in the surroundings of water bodies.
\end{abstract}

Keywords: conservation; road ecology; Hydrochoerus hydrochaeris; mammals; tropical forest.

\section{RESUMO}

A colisão de veículos com mamíferos de grande e médio porte nas rodovias pode causar acidentes sérios, incluindo perda de vidas humanas ou prejuízos materiais significativos. Prever os locais de maior incidência dessas colisões é uma questão relevante para propor medidas de mitigação, e isto é feito pelo uso de modelos que relacionam as ocorrências de colisão com características de paisagem ao seu redor. Capivaras são um dos maiores mamíferos nos trópicos e uma das vítimas mais comuns de colisões com veículos no Brasil. Esse trabalho teve como objetivo determinar quais características da paisagem estão relacionadas ao atropelamento de capivaras ao longo de 180,4 km da rodovia BR-040 entre as cidades de Rio de Janeiro e Juiz de Fora, Sudeste do Brasil. Capivaras foram monitoradas por 4 anos, e 51 atropelamentos foram registrados. As características da paisagem consideradas dentro de $1 \mathrm{~km}$ do atropelamento foram quantificadas como: área urbana, cobertura florestal, cobertura de vegetação herbácea, agricultura e distância do rio mais próximo. Em seguida, modelos de regressão logística foram gerados, e o melhor foi selecionado pelo Critério de Informação de Akaike. A ocorrência de atropelamentos de capivara foi principalmente associada com a proximidade de rios, mas também alta cobertura de vegetação herbácea e baixa cobertura florestal foram relevantes. As características de paisagem relevantes são aquelas relacionadas com o habitat desses mamíferos sociais e semi-aquáticos que preferem estar próximos de áreas abertas e corpos d'água. Algumas medidas de mitigação são propostas para reduzir as colisões com esses animais, incluindo a instalação de placas de sinalização e cercas ao redor de corpos d'água.

Palavras-chave: conservação; ecologia de estradas; Hydrochoerus hydrochaeris; mamíferos; floresta tropical. 


\section{INTRODUCTION}

Motor vehicles colliding with large- and mediumsized mammals on highways may cause serious accidents, including loss of human lives or substantial material damages for the driver (Forman et al. 2003, Huijser et al. 2009). Total expenses from material damages, injuries and human deaths were estimated at more than a billion Euro per year in Europe, and from 23 million to 1 billion dollars in the United States (Seiler $\&$ Helldin 2006). Predicting the sites of the highest incidence of these collisions is a relevant matter to propose mitigation measures, and this can be done using models that correlate collision occurrences with landscape characteristics in the surroundings (Clevenger et al. 2003). Many mitigation measures of animalvehicles collisions were enacted in North America, Europe and Australia (Laurance et al. 2009, Beckmann et al. 2010). When animal-vehicle collisions are included in the cost-benefit estimates for implementing mitigation measures, some options become more economically viable, such as overpasses or underpasses for deer, elk and moose (Huijser et al. 2009).

The costs of animal-vehicle collisions in USA and Europe are high because animals killed on roads there are large, such as elk, moose, deer and bear. In the tropics, mammals are, on average, smaller than in temperate regions. In general, most road-kill species are also highly abundant ones that do not avoid crossing the road (Cáceres 2011, Dornas et al. 2012). In Brazil, the most road-killed species are frogs (Rhinella spp.), reptiles (Helicops infrateniatus and Tupinambis merianea), birds (Crotophaga ani, Athene cunicularia and Volatinia jacarina) and mammals (Didelphis albiventris, Didelphis aurita, Euphractus sexcinctus, Myocastor coypus, Cerdocyon thous and Hydrochoerus hydrochaeris; Dornas et al. 2012). There are some larger mammals with lower road-kill rates, such as, Chrysocyon brachyurus, Myrmecophaga tridactyla, Puma concolor and Panthera onca; Dornas et al. 2012). For vertebrates, one estimate is $8.65( \pm 26.37)$ road-kills $/ \mathrm{km} /$ year, representing $14.7( \pm 44.8)$ million road-kill/year throughout Brazil's territory (Dornas et al. 2012). There is no estimate on the cost of material damage and loss of human lives from such collisions in Brazil. However, based on the high amount of road-kill estimated, even considering that a small portion involves large animals, the cost is expected to be high; especially on toll highways, where the expenses of collisions is a liability for the concessionary company, the cost-benefit of mitigation measures should be positive.

Capybaras are abundant rodents, one of the largest mammals in the tropics (females weighing $50 \mathrm{~kg}$ on average, and males 60kg; Verdade \& Ferraz 2006, Herrera et al. 2011). Moreover, they are the primary victims of vehicle collisions in Brazil (Dornas et al. 2012), and thus, resulting in severe accidents. This work aimed to determine which landscape characteristics are related to the occurrence of capybara road-kills in a tropical forest highway, and to propose mitigation measures.

\section{MATERIAL AND METHODS}

The study site encompass highway BR-040, from $\mathrm{km} 125.2$ to $\mathrm{km} 0$ in Rio de Janeiro State and $\mathrm{km}$ 828.7 to $\mathrm{km} 773.5$ in Minas Gerais State, Southeastern Brazil (Figure 1). Along this $180.4 \mathrm{~km}$ stretch, BR-040 crosses the Biodiversity Corridor the Serra do Mar, whose main native vegetation cover is composed of tropical rain forest (Veloso et al. 1991). The topography varies from the lowlands near Duque de Caxias city (19m high, $22^{\circ} 47^{\prime} 09^{\prime \prime} \mathrm{S}, 43^{\circ} 18^{\prime} 43^{\prime \prime} \mathrm{W}$ ), through the mountain range (about $1,000 \mathrm{~m}$ high) and Petrópolis city (838m high, $22^{\circ} 30^{\prime} 18^{\prime \prime} \mathrm{S}, 43^{\circ} 10^{\prime} 44^{\prime \prime} \mathrm{W}$ ) up to Juiz de Fora city ( $715 \mathrm{~m}$ high, $21^{\circ} 41^{\prime} 20^{\prime \prime} \mathrm{S}$ and $\left.43^{\circ} 20^{\prime} 40^{\prime \prime} \mathrm{W}\right)$. Within this entire range, the road has 2 paved lanes in each direction, and for the stretch crossing the mountain range, the 2-lanes going up and the 2-lanes going down run separately. The BR-040 stretch between Petrópolis and Juiz de Fora was constructed in 1861 by Brazil's Emperor Dom Pedro II (Neto 2001). The stretch between the cities of Petrópolis and Rio de Janeiro was constructed in 1928 by President Washington Luís, and in 1931, it was the first paved road in Brazil. Since 1996, the BR-040 stretch from Rio de Janeiro to Juiz de Fora has been under the authority of a private company, Concer. The mean traffic volume on this road is 20,000 vehicles/day (Concer 2010).

Capybaras killed on the road were recorded daily, for 4 years (from April 2006 to January 2011), along $180.4 \mathrm{~km}$ on BR-040 between the cities of Rio de Janeiro and Juiz de Fora. Concer workers were trained by PhD Cecilia Bueno, Coordinator of the "Caminhos da Fauna" ("Wildlife Pathways") Project, whose main objective is to record road-kills in a 24/7 type schedule, with an estimated average speed of $50 \mathrm{~km} / \mathrm{h}$. 


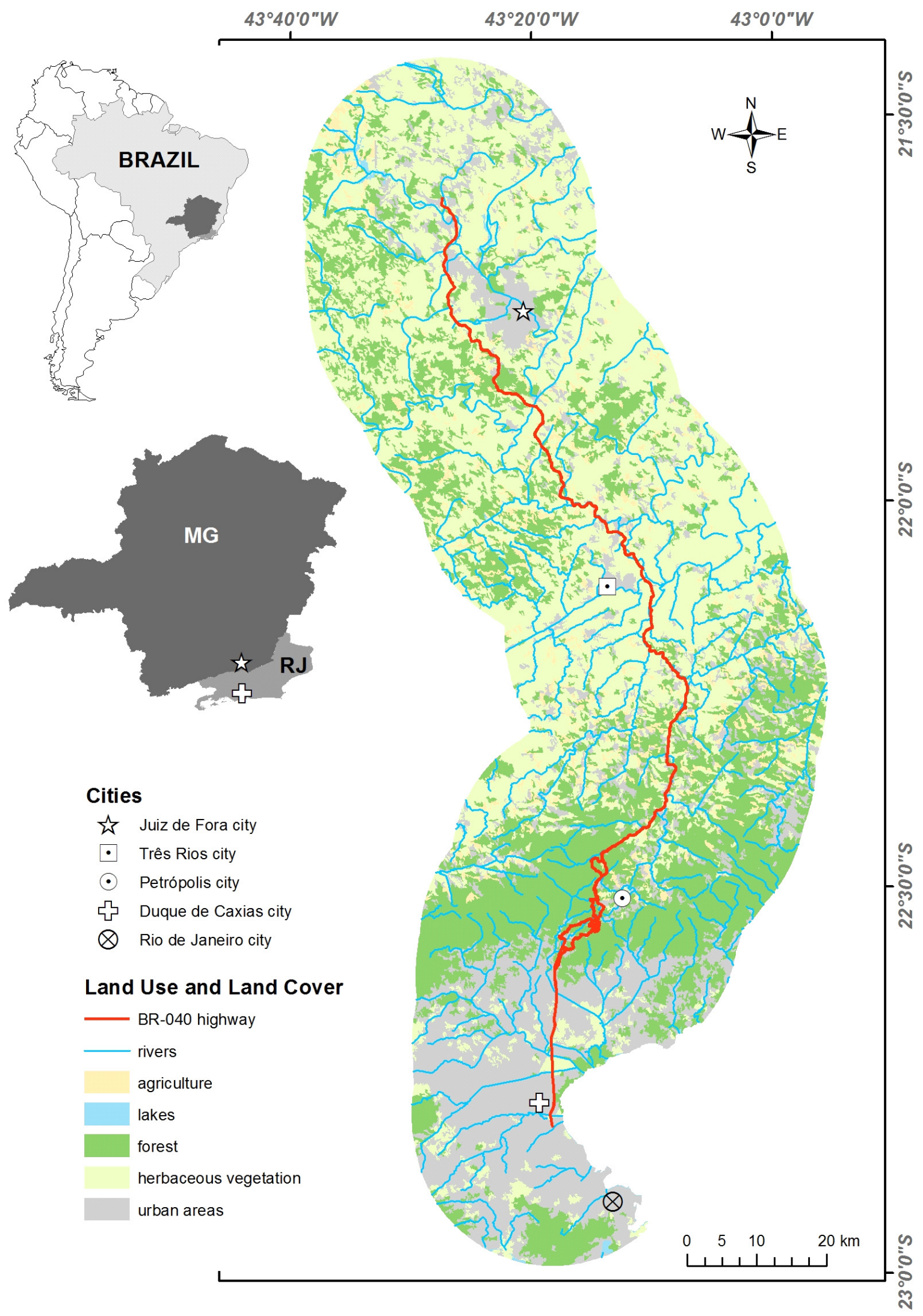

Figure 1. Study area: BR-040 highway stretch where road-kill were recorded, from the km 125.2, near Duque de Caxias city in Rio de Janeiro State (RJ) to the km 773.5, near Juiz de Fora city in Minas Gerais State (MG), Southeastern Brazil. Landscape characteristics 20$\mathrm{km}$ around BR-040 highway are shown in detail. 
The workers used standard forms and techniques, developed for the Caminhos da Fauna Project, which includes taking pictures, removing carcasses, storing in freezers, recording location and time. The Project installed three freezers located at the $104 \mathrm{~km}, 45 \mathrm{~km}$ and $816 \mathrm{~km}$ marks. Twice a month the carcasses were taken to a laboratory at Veiga de Almeida University to be taxidermied and then donated to the National Museum of Rio de Janeiro collection.

A map of land use and land cover of the studied area was made by means of Landsat images of 2002, with a 1:250,000 scale and accuracy of $86.39 \%$ (Iesb 2007). The landscape characteristics within $1 \mathrm{~km}$ of the road-kill were quantified as: urban area, forest cover, herbaceous cover, crop fields. The $1 \mathrm{~km}$ buffer was chosen based on a previous analysis for different distances $(1 \mathrm{~km}, 5 \mathrm{~km}, 10 \mathrm{~km})$, when buffer was included as an independent variable in competing models (Bueno et al. 2011). The distance to the nearest river was also measured. We sorted out the same number of capybara road-kill along the highway to represent absences in logistic regression models. The same landscape characteristics were measured up to 1 $\mathrm{km}$ from each absence point. All landscape measures were done using ArcGIS version 9.3.1. Logistic regression models were designed using presence/absence of road-kills as dependent variables and landscape characteristics as independent variables (Table 1). Afterwards, logistic regression models were generated. The best-fitted model was obtained based on the likelihood of the binomial distribution package using Generalized Linear Models (GLM) in R 2.7.1 (Hornik 2013). The model selection was done using Akaike's Information Criterion with correction for small samples (AICc; Burnham \& Anderson 2002). To sort the best models and evaluate their performance, we used the AIC weight (wi) and evidence (wi_max
/ wi_i; Burnham \& Anderson 2002). We include one null model to compete with other regression models: 1) with a constant (intercept $=1$ ) as independent variable (Table 1).

\section{RESULTS}

Fifty-one capybara road-kill were recorded during the four-year study on the BR-040 highway (Figures 2 and 3). The correlation between forest and herbaceous vegetation was highly significant $(R>0.70)$ and so they were not included in the same regression model (Table 2).

Capybara road-kills were associated with river proximity. Two other models were also considered relevant: (1) including river proximity and higher cover of herbaceous vegetation, and (2) including river proximity and lower cover of forest cover. All selected models showed a better performance than the null model (Table 3).

Table 1. Competing models used in Akaike's Information Criterion (AIC) selection, where dependent variables were presence or absence of capybara's road-kill in the BR-040 highway.

\begin{tabular}{cc}
\hline Model & Independent variables \\
1 & Herbaceous vegetation \\
2 & Herbaceous vegetation + Agriculture \\
3 & Herbaceous vegetation + Urban areas \\
4 & Herbace ous vegetation + Distance of the nearest river \\
5 & Agriculture \\
6 & Agriculture + Urban areas \\
7 & Agriculture + Forest \\
8 & Agriculture + Distance of the nearest river \\
9 & Urban areas \\
10 & Urban areas + Forest \\
11 & Urban areas + Distance of the nearest river \\
12 & Forest \\
13 & Forest + Distance of the nearest river \\
14 & Distance of the nearest river \\
Null & 1 \\
\hline
\end{tabular}

Table 2. Correlations between independent variables.

\begin{tabular}{lrccr}
\hline & Agriculture & Urban areas & Forest & $\begin{array}{c}\text { Distance of the } \\
\text { nearest river }\end{array}$ \\
Herbaceous vegetation & -0.060 & $-0.517^{*}$ & $-0.808^{*}$ & -0.020 \\
Agriculture & & $-0.261^{*}$ & 0.006 & -0.171 \\
Urban areas & & & -0.041 & -0.078 \\
Forest & & & & 0.126 \\
\hline
\end{tabular}

Note: $* \mathrm{p}<0.01$. 


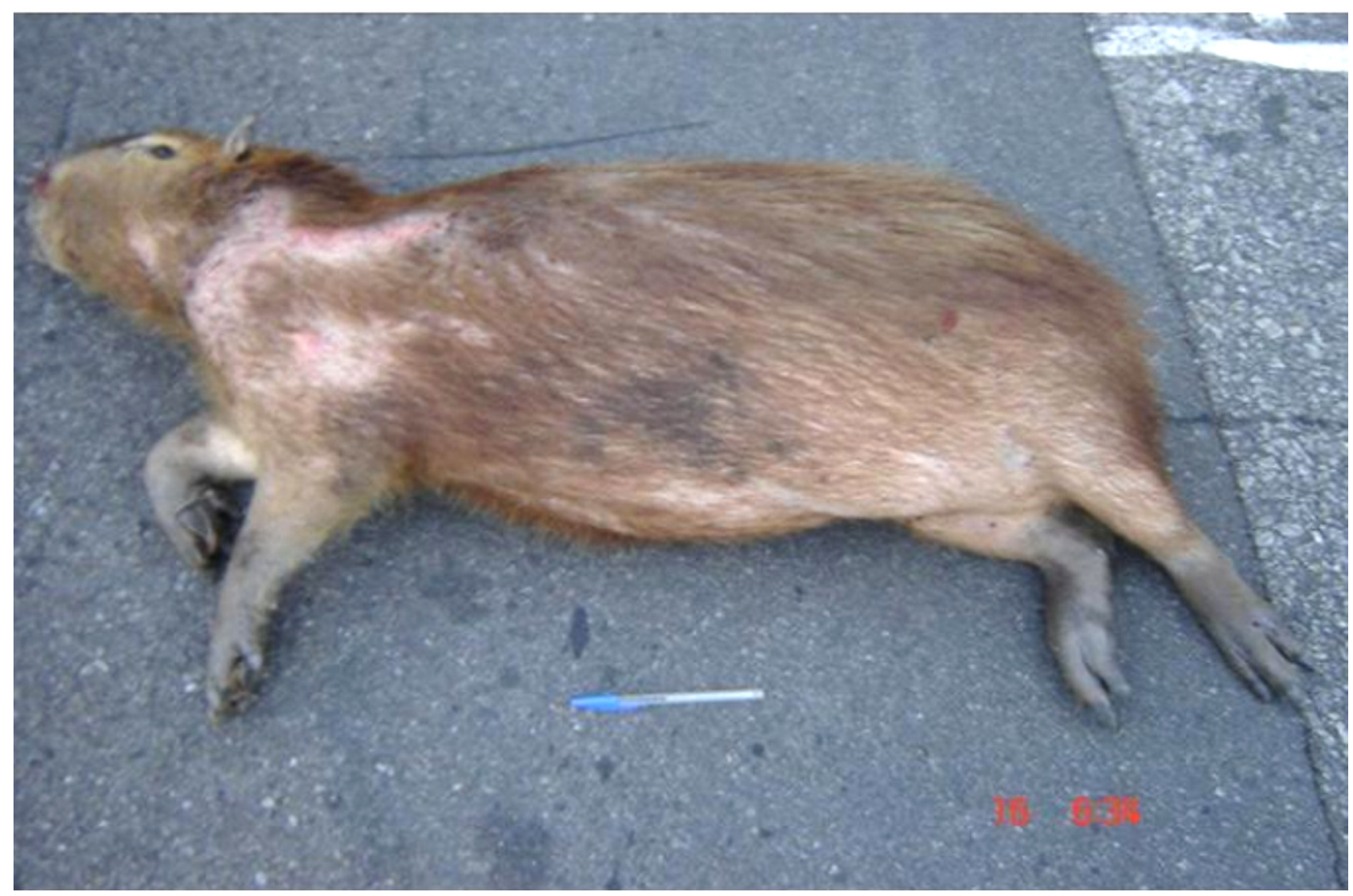

Figure 2. Capybara killed by vehicle collision on BR-040 highway. Photograph taken by Cecilia Bueno.

\section{DISCUSSION}

The rate of 12.75 capybaras/year found in BR040 is suspected to underestimate the actual number of road-kill since some capybaras could be hurt in a collision and die outside the monitored strip, far from the road. According to Dornas et al. (2012), they are one of the most road-killed vertebrates in Brazil. Collisions with animals weighing $50 \mathrm{~kg}$ (females) or $60 \mathrm{~kg}$ (males) on average, such as capybaras, are a relevant concern for driver safety. These collisions usually cause severe accidents, including injuries to people and deaths (Barszcz 2012). In Brazil, there is no estimate of the financial losses due to this kind of accident. In the United States and Canada, estimated costs for the average deer-, elk-, and moose-vehicle collisions were US\$ 18,287 per kilometer per year, on average (Huijser et al. 2009). Despite that large mammals are more common in temperate regions, it is expected that collisions between vehicles and wildlife also cause significant expenses and loss of human lives in the tropics, indicating the relevance of investments in mitigation measures.
Capybaras are social and herbivorous mammals that live along riverbanks covered by herbaceous vegetation (Herrera et al. 2011). They are also found in agro ecosystems near rivers, such as open areas covered by sugar cane or pasture (Ferraz et al. 2007). The association found between capybara road-kills, river proximity and herbaceous vegetation represents the main characteristics of its habitat. The habitat preference of capybaras for open vegetation instead of forested areas was confirmed by the road-kill patterns (Ferraz et al. 2007). Thus, where roads cross this kind of environment, the chances of an accident are higher. For the capybaras grazing in groups (Herrera et al. 2011) and more active at night, roadkill chances are even higher.

The association of capybara road-kills to river proximity and the damages caused by the collisions with vehicles and injured people strongly suggest the need to adopt wildlife underpasses and fences. We suggest that culverts should be modified and made wider in order to avoid flooding and provide a semiaquatic environment similar to capybara habitats. Fences are needed to induce underpass usage and thus 
reduce kills. In this case, however, maintenance is very important (Mata et al. 2005, Beckmann et al. 2010). The BR-040 highway is located in a mountain region, thus some stretches where a river meets the highway have a rocky wall on one bank. In this case, wildlife passages should not be installed because they would connect one side of the highway to a wall. In this case, it is suggested that only fences be installed to prevent the animals from crossing the highway. In addition, clear road signs warning about capybaras crossing the road and any kind of arrangement that causes drivers to reduce their speed is recommended.

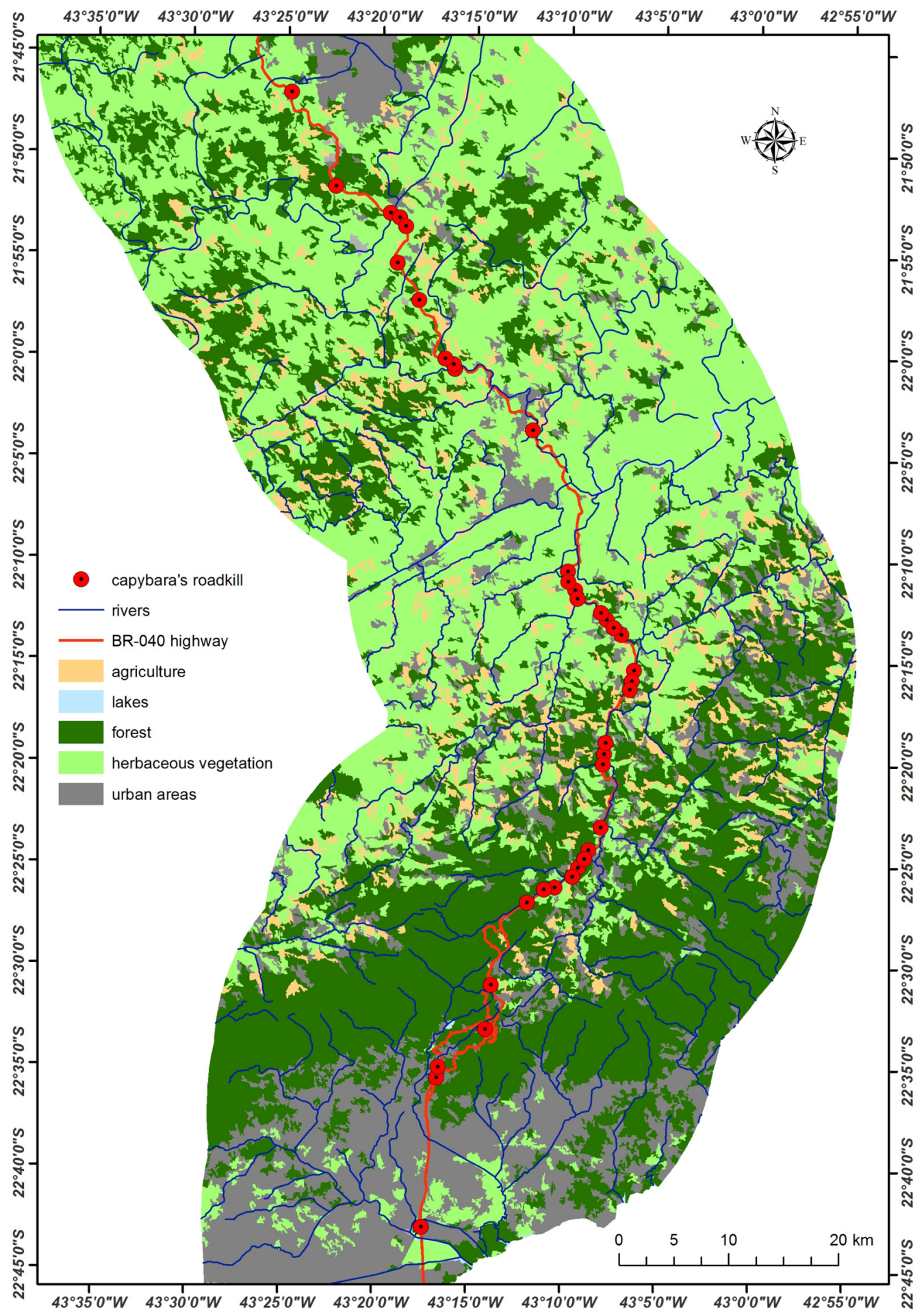

Figure 3. Capybara's road-kill events along the BR-040 highway. 
Table 3. Regression models selected by AICc (Evidence d" 2) to explain road-kill of Hydrochoerus hydrochaeris ( $\mathrm{n}=51$ ).

\begin{tabular}{llrrr}
\hline Dependent Variables & \multicolumn{1}{c}{ Independent Variables } & AICc & wAIC & Evidence \\
\hline & - distance of the nearest river & $\mathbf{1 3 5 . 0 1}$ & $\mathbf{0 . 3 2 1}$ & $\mathbf{1 . 0}$ \\
Capybara road-kill & - distance of the nearest river $\quad$ + herbaceous vegetation & 135.95 & 0.201 & 1.6 \\
& - distance of the nearest river $\quad$ - forest & 135.98 & 0.198 & 1.6 \\
& constant & 143.50 & 0.005 & 69.1 \\
\hline
\end{tabular}

Note: where constant $=1$.

\section{CONCLUSION}

Motor vehicles colliding with capybara represent a serious risk for drivers. The study found that capybara road-kill occurred mainly near rivers and where herbaceous vegetation is predominant. It is suggested that culverts should be modified and made wider to facilitate their use by capybaras as underpasses, and fences should be installed to induce them to go through the underpasses. These measures are expected to reduce capybara-vehicle collisions and the consequent loss of human and capybara lives.

ACKNOWLEDGMENTS: We are thankful to the anonymous reviewers for invaluable comments on this manuscript. We are grateful for support of Concer. Jim Hesson of AcademicEnglishSolutions.com proofread the English.

\section{REFERENCES}

BARSZCZ, L.B. 2012. Avaliação dos acidentes entre veículos e animais no Brasil com base em notícias de jornais eletrônicos. Monografia de Graduação. Universidade Federal do ABC. Santo André, São Paulo, Brasil. 19p.

BECKMANN, J.P.; CLEVENGER, A.P.; HUIJSER, M.P. \& HILTY, J.A. 2010. Safe passages: highways, wildlife, and habitat connectivity. Island Press, Washington. 396p.

BURNHAM, K.P. \& ANDERSON, D.R. 2002. Model selection and multimodel inference: a practical information-theoretic approach. Second Edition. Springer, New York. 488p.

BUENO, C.; SOUSA, C.O.M. \& FREITAS, S.R. 2011. O atropelamento de capivaras (Hydrochoerus hydrochaeris) e sua relação com a paisagem no entorno da rodovia BR-040. Pp. 129142. In: A. Bager (ed.). Anais do Road Ecology Brazil 2011. Lavras, Brasil. 264p.

CÁCERES, N.C. 2011. Biological characteristics influence mammal road kill in an Atlantic Forest-Cerrado interface in southwestern Brazil. Italian Journal of Zoology, 78: 379-389. http:// dx.doi.org/10.1080/11250003.2011.566226.

CLEVENGER, A.P.; CHRUSZCZ, B. \& GUNSON, K.E. 2003. Spatial patterns and factors influencing small vertebrate fauna road-kill aggregations. Biological Conservation, 109: 15-26. http:/
/dx.doi.org/10.1016/S0006-3207(02)00127-1 .

CONCER. 2010. Relatório de Impacto Ambiental da nova subida da Serra: BR-040 trecho Rio-Petrópolis. Relatório técnico. <http:/ /www.cmp.rj.gov.br/planodiretor/pdf/EIA\%20-\%20RIMA/ RIMA/ EIA_CONCER_RIMA_REV31corrigido.pdf $>$. (Accessed on 01/05/2012).

DORNAS, R.A.P.; KINDEL, A.; BAGER, A. \& FREITAS, S.R. 2012. Avaliação da mortalidade de vertebrados em rodovias no Brasil. Pp. 139-152. In: A. Bager (ed.). Ecologia de Estradas: tendências e pesquisas. EDUFLA, Lavras. 314p.

FERRAZ, K.M.P.M.B.; FERRAZ, S.F.B.; MOREIRA, J.R.; COUTO, H.T.Z. \& VERDADE, L.M. 2007. Capybara (Hydrochoerus hydrochaeris) distribution in agroecosystems: a crossscale habitat analysis. Journal of Biogeography, 34: 223230. http://dx.doi.org/10.1111/j.1365-2699.2006.01568.x .

FORMAN, R.T.T.; SPERLING, D.; BISSONETTE, J.A.; CLEVENGER, A.P.; CUTSHALL, C.D.; DALE, V.H.; FAHRIG, L.; FRANCE, R.; GOLDMAN, C.R.; HEANUE, K.; JONES, J.A.; SWANSON, F.J.; TURRENTINE, T. \& WINTER, T.C. 2003. Road ecology: science and solutions. Island Press, Washington. 481p.

HERRERA, E.A.; SALAS, V.; CONGDON, E.R.; CORRIALE, M.J. \& TANG-MARTÍNEZ, Z. 2011. Capybara social structure and dispersal patterns: variations on a theme. Journal of Mammalogy, 92: 12-20. http://dx.doi.org/10.1644/09-MAMM$\underline{\mathrm{S}-420.1}$.

HORNIK, K. 2013. The R FAQ. <http://CRAN.R-project.org/ doc/FAQ/R-FAQ.html>. (Accessed on 01/052013).

HUIJSER, M.P.; DUfFIELD, J.W.; CLEVENGER, A.P.; AMENT, R.J. \& MCGOWEN, P.T. 2009. Cost-benefit analyses of mitigation measures aimed at reducing collisions with large ungulates in the Unites States and Canada: a decision support tool. Ecology and Society, 14: 15.

IESB (Instituto de Estudos Socioambientais do Sul da Bahia). 2007. Levantamento da Cobertura Vegetal Nativa do Bioma Mata Atlântica. Relatório técnico. Instituto de Estudos Socioambientais do Sul da Bahia (IESB), Rio de Janeiro. 84p. < http:// ambienteduran.eng.br/system/files/publicador/PUBLICACOES/ MATA\%20ATLANTICA\%20relatorio_final.pdf > (Accessed on 01/052013).

LAURANCE, W.F.; GOOSEM, M. \& LAURANCE, S.G.W. 
2009. Impacts of roads and linear clearings on tropical forests. Trends in Ecology and Evolution, 24: 659-669. http://dx.doi.org/ 10.1016/j.tree.2009.06.009.

MATA, C.; HERVÁS, I.; HERRANZ, J.; SUÁREZ, F. \& MALO, J.E. 2005. Complementary use by vertebrates of crossing structures along a fenced Spanish motorway. Biological Conservation, 124: 397-405. http://dx.doi.org/10.1016/j.biocon.2005.01.044 .

NETO, O.L. 2001. Transportes no Brasil: história e reflexões. Empresa Brasileira de Planejamento de Transportes (GEIPOT), Brasília. 525p.

SEILER, A. \& HELLDIN, J.-O. 2006. Mortality in wildlife due to transportation. Pp. 165-189. In: J. Davenport \& J.L. Davenport (eds.). The ecology of transportation: managing mobility for the environment. Springer, Dordrecht. 392p. http://dx.doi.org/ 10.1007/1-4020-4504-2 8 .

VELOSO, T.H.; RANGEL-FILHO, A.L.R. \& LIMA, J.C.A. 1991. Classificação da vegetação brasileira adaptada a um sistema universal. Instituto Brasileiro de Geografia e Estatística (IBGE), Rio de Janeiro. 124p.

VERDADE, L.M. \& FERRAZ, K.M.P.M.B. 2006. Capybaras in an anthropogenic habitat in southeastern Brazil. Brazilian Journal of Biology, 66: 371-378. http://dx.doi.org/10.1590/S151969842006000200019. 